\title{
A VÁLLALAT PARADIGMA
}

\author{
Csányi Tamás
}

\begin{abstract}
Absztrakt: A világgazdaság az IT és az ipar forradalmának hatására gyors átrendezödés folyamatában áll. Ez nem egyszerüen iparágak vagy országok, de a gazdasági intézmények szerepének változását is jelentheti. A cikk a töke, a piac és a vállalat hármasára épülō paradigma esetleges változását elemzi. Következtetése az, hogy a vállalat szerepváltozása lesz eröteljes.
\end{abstract}

Abstract: The world economy is undergoing rapid reorganization as a result of the IT and industry revolutions. This is not simply an industry or a country, but also a change in the role of economic institutions. The article analyses the possible changes in the capital, market and company paradigm. The consequence is that the company's role change will be characteristic.

Kulcsszavak: piac, tökés társadalom, vállalat, IT forradalom, sharing economy

Keywords: market, capitalist society, company, IT revolution, sharing economy

\section{Bevezetés}

A modern gazdaság számos jelensége olyan képet és fordulatokat hoz, ami elbizonytalanítja a szemlélőt, hogy vajon ezek a tendenciák a piacgazdaság fejlödésének új területei, vagy esetleg egy gyökeresen másféle integráló séma megjelenése, vagy akár az egész „termelési mód” (a kapitalizmus) átváltozása lenne. Csak néhány ilyen vonás: a vállaltok közt megfigyelhetö hálózatok kikristályosodása, az infotechnika viharos fejlödésére épülő üzleti modellek (az egész sharing economy), az M2M és a termelési eljárások soha nem látott mértékü automatizálása stb.

Az emberiség gyakran hajlamos azt hinni, hogy az éppen aktuális korszak jelent valami igazán nagy fordulatot, ezért tanácsos óvatosan, többféle szempontból értelmezni a tényeket, ezt a hibát elkerülendő.

A modern gazdaság a tőkére, mint elsődleges erőforrásra épülö, piaci sémák által integrált gazdaság. Az állami szerepvállalás érdemi, de egyre kevésbé meghatározó elem, a gazdasági tér pedig lényegében az egész világra kiterjed - az maga a globalizáció egyik látványos jele.

A paradigma szó legáltalánosabban elfogadott értelmezését Thomas Kuhn (1984) adja meg, e szerint a paradigma gondolkodási modell, a korszellem által meghatározott gondolkodás, mely meghatározza világképünket.

Tudományos világunkban a paradigma magában foglalja azt az emberi (szakmai) közösséget, amelyik egyazon fogalmakkal, módszerekkel, és következtetési logikával igyekszik a világ tényeit logikus rendben értelmezni.

A mai közgazdaságtudomány - számos iskolája ellenére - közös abban, hogy a gazdaság valódi alapja és színtere a piac, alanyai közt biztosan ott vannak a vállalatok, és a hajtőereje mindenféle változásnak a tőke megtérülés - vagyis a kapitalizmus.

Az alábbiakban arra teszek kísérletet, hogy a fent jelzett új, és forradalmi tendenciákat megkísérlem értelmezni, hogy van-e köztük olyan, ami vélhetően kivezet ebböl, ezt meghaladó új séma előjelének (is) tekinthetjük. 
2. A piac

A piacról szóló klasszikus elméletek alapját Adam Smith adta, de könyvtárnyi irodalom született különféle feltételeiröl, és müködésmódjáról. A ,tökéletes piac” is számos meghatározással rendelkezik, ezeket talán Kornai János szedte legteljesebb, - bár kicsit talán túl - elméleti keretbe (Kornai, 1971):

- Egyenlő résztvevők.

- Nagyszámú résztvevő.

- Csak termelök és fogyasztók léteznek.

- Statikus/stacioner jelleg.

- A termékkör állandó.

- Szimultán müködés.

- Nincs készlet semmilyen formában.

- Nincs időbeli eltolódás.

- Az eröforrások folytonosak.

- A döntés csak az árinformáció alapján történik.

- Az informáltság tökéletes.

- A viselkedést csak maximalizálás vezérli (profit, fogyasztói haszon).

Ezeknek az axiómáknak (ahogy Kornai nevezi) egy részéröl tudjuk, hogy logikai kényszer eredményei, vagyis nem a valóság valami általános absztrakt összefüggéseinek megjelenése. Ilyen a maximalizálás, mint viselkedési vezérelv. Az a féle szikár racionalitás, amit pl. a fogyasztói összhaszon maximalizálása megkövetelne (a rendezett preferencia skálával) nem sajátossága az emberi gondolkodásnak.

A vállalatok profitmaximalizálása sem közvetlenül az eredményelszámolás utolsó soraira - vagyis nem az adózás előtti eredményre vonatkozó törekvés.

Az axiómák másik részéröl látjuk, hogy a modern világban kétségtelenül közelebb jutunk ezek realizáláshoz. Ilyen pl. az időbeli gap-ek eltünése.

Amit a fókuszba szeretnék állítani az a harmadik axióma, miszerint a gazdaságban (s így a társadalomban is) csak termelök vagy fogyasztók léteznek. Ennek az egyik ki nem mondott további feltételezése, hogy a két kör jól elkülöníthető, továbbá, hogy a termelö vállalatként van jelen a piacon. kerete.

A vállalat a legjobb definíció szerint a vállalkozási tevékenység szervezeti

A jelenlegi gyors változások egyik hajtóereje, és egyben következménye is, hogy ezek a keretek dinamikussá váltak, majdhogynem légiesültek.

Ez nagyon alapvető változást jelent a gazdaság müködésében, de a piac paradigmával kapcsolatos gondolkodásunkban is.

$\mathrm{Az}$ Adam Smith idejében értett vállalat világos keretekkel, tulajdonosi körrel, tevékenységgel, gyárteleppel, versenytársakkal, vevőkkel és szállítókkal bírt. Viszonylag egyértelmüen meghatározott tevékenységi körrel és földrajzilag is definiált piacon müködött.

Az egymástól független, és nagyjából egyenlő erejủ versenytársak világa - ha létezett egyáltalán - lassan módosulni kezdett. 
Ennek gazdaságtörténeti követése is igen érdekes tanulmány volna, de erre nem vállalkozunk. A hálózati müködés már nyilván a legelső idöktől modifikálta ezt az idilli képet, azon hálózatok létével, melyek az üzlet sajátosságaiból hálózatok, mint pl. a bank.

A monopolizáció a versenyben előállók természetes törekvése, erröl már a XX. század elején is sokan írtak aggodalommal. A piacokon tapasztalható koncentráció következtében egyes területeken ma már szinte csak oligopol vagy monopol kategóriákkal írható le, és persze a természetes monopóliumok is végig jelen voltak.

Ezek a tendenciák bár folyamatosan gyengítik a „tökéletes piac” által meghatározott képet beleillenek abba, hiszen azokból az eredetböl táplálkoznak.

A tömegtermelés növekedésével az alacsony áron túl megjelent a kockázat is, mint lényegi beszerzési szempont, ez adja az alapját az ellátási láncok stabilizálódásának. Ez szintén egy olyan jelenség, ami kifelé mutat a klasszikus piaci séma leírásából, de azzal a kiegészítéssel még belül tartható, hogy a profit maximalizálása nem rövid, hanem hosszú távú, tartós cél.

Az ellátási láncok nyomán vertikális stratégiai szövetségek alakultak ki, ahol a korábban önálló, világos keretekkel és célrendszerrel müködő vállalatok a saját céljaikat már egy tágabb kör igényeihez igazítják - tehát a „láthatatlan kéz” helyett egy láthatóbbat követnek.

A célok hierarchiájában a távlatibb, de mindenképpen magasabb szintü „objectives” dominanciája a közvetlenebb vagy rövidebb távú „goals" felett - amit talán az éves profit maximalizálásával tehetünk egy szintre.

A vertikális mellett megjelenő horizontális szövetségek és a több országban üldözött kartellek tevékenysége csak gondos megfigyeléssel választható szét - de szintén csak a rövid / hosszú táv szétválasztásával tekinthetjük klasszikus felfogású piacgazdaság elemének.

Ezek a változások még csak annyit jelentenek, hogy a mindenki-mindenki ellen klasszikus piacgazdasági környezetben a szereplő egy része között a verseny mellett a kooperáció bizonyos formái is megjelennek.

Az igazi változást a vállalat kereteinek változása jelenti, két szálon is, ezek a felvásárlások és a kiszervezések - pontosabban ezek tömegessé válása.

Ezek az üzleti gyakorlat lépései, a vállalat elméleti alapjaikat, illetve magyarázataikat két iskola eredményei bemutatására két vállalatelméleti iskola, az intézményi közgazdaságtan és az eröforrás alapú elméletek tünnek relevánsnak.

\section{A vállalat, az intézményi közgazdaságtan megközelítésében}

$\mathrm{Az}$ intézményi közgazdaságtan vállalatelméleti szempontból egyik legfontosabb sarokpontja a tranzakciós költségek elmélete. Coase álláspontja szerint (1937) nem csak a termelés, de a specializáció körülményei közötti csereaktusok költségesek ami egy kibővítése, vagy pontosítása a klasszikus modellnek.

További megállapítás, hogy az egyik ilyen költség maguknak a releváns költségtételeknek a meghatározása (Coase, 1937).

Ezek a költségek többfélék: az árinformáció megszerzése és a szerzödés megkötése is terheli a feleket, avagy, ezeket elkerülendő módon, az irányítás 
költségei nőnek. Ha a piaci csere költségei magasak, bizonyos cseréket azon kívül, hosszú távú megállapodások alapján fogják megtenni, mely megállapodások hierarchiákat hoznak létre, ami stabilizálja a szervezeteket, és ez a hatékonyság igazolja létüket közgazdasági szempontból is.

A vállalat tehát addig terjed, amig a cserékhez hatékonyabb feltételeket biztosít, mint a piac.

North, (1986) felmérést készítettek az Egyesült Államokban a tranzakciós költségek nagyságára vonatkozóan (beleértve a banki, biztosítási, finanszírozási kiadásokat, a nagykereskedelmi és kiskereskedelmi eladásokat is) és azt a megállapítást tették, hogy a bruttó nemzeti jövedelem több mint $45 \%$-a valamilyen formában az ügyletek lebonyolítására fordítódott, vagyis igen jelentős, időben növekvő arányt képvisel. További észrevételük volt, hogy ez az arány 25\%-kal növekedett az elmúlt száz év során. Mivel ezek a költségek a termelési folyamat részeként foghatók fel, ezért a tradicionális termelés definíció kiegészítésre szorul a következöképpen: a termelés teljes költsége a földterület, munka és tőke költsége, amely nemcsak a jószág fizikai tulajdonságainak megváltoztatására során kerül felhasználásra, hanem a folyamattal együtt járó tranzakciók során is (North, 1990).

A termelés irányításának költségeire vonatkozó aggodalmak miatt a nemzetközi termelési láncok analízisét gyakran összekapcsolják a vállalat tranzakciós költségeinek elméletével, amely a tranzakciós költségekre és a vállalat vagyontárgyainak egyediségével foglalkozik. Az elmélet szerint a vállalatok szerződéses kapcsolatok által alkotott irányítási szerkezetek, melyek elsődleges célja megrendelések szerzése, konfliktusok csökkentése, valamint ez által a profit maximalizálása a tranzakciós költségek lecsökkentésével. A vállalat létét az elmélet azzal magyarázza, hogy az hatékonyabban képes müködni, mint a piaci viszonyok. A megközelítés ezzel szakít a neoklasszicista vállalatelméletekkel, mely szerint a vállalatot egy adott termelési funkció és a profitmaximalizálás célja definiál.

A belső vállalati gyakorlatban, ahol egyre égetőbb probléma a termék költségek maghatározása, az Activity Based Costing metódus jelenti a problémamegoldás releváns lépését. Talán meghökkentően magas a Wallis és North felmérésében mutatkozó tranzakciós költségek magas szintje, de hasonlóan meghökkentő a vállalati költségszerkezetben az ,általános” - vagyis termékhez nem rendelhető költségek aránya is. P. Horvathon kívül erröl írnak a magyar szakértők is: „,Korábban az általános költségek aránya a vállalati költségstruktúrán belül 5-20\%, mostanra ez az érték átlagosan 30-60\%, de sok helyen elérheti a 80-90\%-ot is." (Dr. Sztanó Imre, Veress Attila, 2013)

Ez a kiélezett piaci versenyben a korábbi egyszerü osztókalkulációnál lényegesen nagyobb felelösségek, bonyolultabb megoldásokat és drágább eszközöket igényel a költségek lehetőség szerinti pontos meghatározásához, mert a piacon a fillérekért folyik a küzdelem.

Ez alátámasztja Coase fenti állítását, miszerint magának a költségnek a meghatározása is költséggel járó folyamat.

Az elemzés alapelve a vállalat reálfolyamatait követő logikai kapcsolódások explicitté tétele, „minek az érdekében” áll elő egy nevesített költség? Nyilvánvalóan 
így sem tudunk mindig, minden tételre kielégítő és kizárólagos magyarázatot adni, de az általános költség-felhő nagyobb csoportjaiból jó esetben ki lehet választani olyan tömböket, ahol egy-egy termelési vonallal felmutatható az oksági összefüggés.

Ilyen lehet a gépbeállítás költsége, egyes adminisztratív tevékenységek költsége, a beszerzéssel járó járulékos, és azonosítható ráfordítások. Ezek jelentős része megegyezik a „tranzakciós költségek” elméleti fogalmával.

A tranzakciós költségek magukban foglalnak minden olyan áldozatot, hátrányt, melyek felmerülnek a felek viszonyában, amikor termékek vagy szolgáltatások cserélnek gazdát. Ide sorolhatjuk az információgyüjtés és kommunikációs költségeket, melyek ex ante merülnek fel, a megállapodás megkötésével felmerülö költségeket (jogi, menedzsment), valamint az ex post felmerülö költségeket (kontroll, szerződésmódosítás). Fontos megjegyezni, hogy ezek a lépések a gyakorlatilag minden szerzödés megkötésekor felmerülnek, tehát nem úgy tekintendök, mint további költségek, hanem egyszerüen a tipikus, elfogadott folyamat költségei (Milberg-Winkler, 2013).

Williamson kiegészítette a Coase által létrehozott struktúrát a globalizált termelés szempontjából releváns szempontokkal. Az első fontos megállapítása, hogy a vállalat, mint szervezet, a belső bürokratikus koordinációjával hatékonyabban müködhet, mint a piac (Williamson, 1996). A tényt, hogy a vállalatok egyes termékeket és szolgáltatásokat nem a piacról szereznek be, hanem maguk hozzák létre, a piac kudarcának tekinti, különös tekintettel a termékek és a tökepiac vonatkozásában. Tehát vállalatok azért léteznek, mert hatékonyabban gazdálkodnak a tranzakciós költségekkel, mint a piac.

A vállalatoknak információs előnye van a piaccal szemben, ezért a vállalat vezetése hatékonyabban tudja irányítani a divíziók munkáját, mint azt a piac tenné, ha ezeket a divíziókat külön cégekként képzelnénk el. A hierarchia megléte is elösegítheti a hatékonyság növelését, erre magyarázatot a hiányos szerződések adnak. Williamson szerint minden komplex szerzödés természetéböl fakadóan nem teljes, ami miatt a feleknek konfrontálódniuk kell, hogy ezeket a hézagokat kitöltsék. A környezet, melyben ezek a szerződések születnek bizonytalan, valamint a felek korlátozott racionalitásának feltevésével is élhetünk, természetesen egy „teljes” szerzödés nem elérhetö.

Williamson hangsúlyozza, hogy az erőforrások egyediségének foka a másik fontos szempont az internalizáció mellett. Megkülönböztet egyedi fizikai erőforrásokat, emberi erőforrásokat, helyszíni erőforrásokat és a márka tőkéjét. Ennek megfelelöen az egyedi tranzakciók helyszín-specifikus létesítményekben, specifikus gépek, technológiák használatával kvalifikált munkaerő segítségével jönnek létre. Minél nagyobb a termelési folyamatban részt vevö elemek egyedisége, a hierarchia hatékonysága annál nagyobb a piaci alapú szervezethez képest. Ez a szemlélet hibrid irányítási módok lehetőségéhez vezet (Milberg-Winkler, 2013).

Az értékláncok

A hibrid irányítási módok különösen fontosak a nemzetközi értékláncok vizsgálatakor. 
A vezető cégek együttmüködnek, képzik és támogatják partner cégeiket annak ellenére, hogy bennük sem tulajdoni hányaduk, sem belső ellenőrzési hatáskörük. Gereffi és munkatársai (2005) három fö hibrid irányítási formát különböztetnek meg:

- Moduláris értéklánc. Moduláris termelési lánc esetén sok beszállító lát el egyetlen, a végleges terméket gyártó/összeszerelő vállalatot, amely a vezető vállalat beszállítója.

- Összefüggő értéklánc. Összefüggő termelési lánc esetén magas fokú interakció és technológia megosztás van a vezető vállalat és az első számú beszállítói között.

- Rögzített értéklánc. Rögzített termelési lánc esetén a vezető cég közvetlenül szerződik nagyszámú, de kis beszállítóval.

A piaci tranzakciós költsége megkeruilésének ára az irányítási költségek növekedésében jelentkezik. Hozzá kell tenni, hogy a költségek puszta növekedés nem elégséges tényező a kalkulációban, mert ezen túl fellépnek kockázatnövelö tényezök, a rendszer bonyolultságnak növekedéséből fakadóan.

A tranzakciós költségek elmélete a globalizált termelés tendenciáinak értelmezéséhez is segítséget nyújt. A szállítás és kommunikáció költségeinek csökkenése csökkentette a piaci szervezetek költségeit (és a hierarchia költségeit is). Továbbá azt is láthatjuk, hogy a beszállítók is a moduláris termelés felé hajlanak, mivel a tranzakció-specifikus beruházások a beszállítók alkupozícióját a vevőkkel szemben jelentősen csökkentik. Mivel az alvállalkozók számítanak hasonló helyzetekre, ezért minél általánosabb befektetések megtételére törekednek, melyeket szélesebb körben tudnak alkalmazni, azonban ezek a megoldások hatékonyságban elmaradnak az optimálistól.

Langlois (2003) és Coase (1937) tanait követve a független nemzetközi tranzakciók számának emelkedését a piaci tranzakciós költségek csökkenésének tulajdonítja, melyet a technológia megváltozása, valamint a gyártási folyamatban megfigyelhetö csökkenö specifikusság okozott.

A tranzakciós költség megközelítés rengeteg matematikai outsourcing-modell létrejöttét segítette elö. A hiányos szerződések több modellben is magyarázatként szolgálnak a make or buy döntés meghozatalában. Grossman és Helpman (2005) a megfelelö beszállító megtalálásának, valamint a szerződés hiányosságának fokát hangsúlyozza. Outsourcing akkor hatékony, amikor a specializált termék, vagy szolgáltatás megvásárlásával létrehozott költségmegtakarítás meghaladja a fent említett, valamint a folyamatban rejlő veszélyek költségeit. Összefoglalva a vállalat make or buy döntése is egy kompromisszum a tranzakciós költségek és a vertikális integrációval járó extra irányítási költségek között (Milberg-Winkler, 2013).

Amikor a termék piaca kompetitív, a specializált alapanyag beszállítóknak nagy költségelönnyel kell termelniük az integrált vállalatokhoz képest, hogy ellensúlyozzák a beszállítókeresés költségeit és az árazási problémákat. Ha a piac nem versenyző, akkor az outsourcing életképessége pusztán a fix költségek összehasonlításából származtatható. Ezért Grossman és Helpman az outsourcing növekedésének lehetőségét nem csak a költségcsökkentésben látja, amely a beszállítói szintü többletkapacitásból származik, hanem a keresési költségek 
csökkenésében is, amely a potenciális beszállítók számának növekedéséből fakad (Milberg-Winkler, 2013).

A tranzakciós költségeket értelmező teóriák és modellek kielégítő magyarázatot adnak arra nézve, hogy a vállalat, mint szervezetnek a határa miért lettek ilyen dinamikussá az elmúlt fél évszázad alatt. Azt is leszürhetjük, hogy ezek a kiegészítések a klasszikus piacgazdasági axiómákhoz tulajdonképpen pontosítások, az elvont elveknek a gyakorlat felé való - hatékony - közelítése, tehát nem indikálják a piacgazdasági paradigma elvetését.

Az integráló sémák, vagy, ahogy Kornai nevezi koordinációs mechanizmusok egymással is versenyeznek, az outsourcing esetében a piac az erösebb az insourcing idején pedig a szervezeti, bürokratikus koordináció.

\section{A vállalat, az eröforrás alapú vállalatelméletek alapján}

$\mathrm{Az}$ insourcing legerőteljesebb formája a vállalatfelvásárlás. Ennek szintén az utóbbi négy-öt évtized hozta el a virágkorát, két mozgatóerejét érdemes megemlíteni az eddigieken túl: a szinergikus növekedési lehetőségeket, és a speciális erőforrások megszerzésének lehetőségét.

Ez utóbbi kérdéskör az erőforrás alapú vállalat elméletek és magyarázatok világa, amit szintén érdemes röviden áttekinteni.

Ezen elméletek ősforrásának talán David Ricardo által 1817-ben megalkotott komparatív előny klasszikus elméletét tekinthetjük. Ez a közismert magyarázat a nemzetgazdaságok szintjén értelmezte a tágan vett kedvezö erőforrás, illetve annak birtoklásának a kihasználható előnyeit.

A modern időkben az elméletet kiteljesedését Penrose (1959) és Wernerfelt (1984) tanulmányai indították el.

A vállalatok erőforrásai és azok felhasználásának képességei eltéröek, ebböl az eltérésből versenyelőny származhat. Tehát az kerül elönyös helyzetbe, aki olyan erőforrásokkal rendelkezik mely mások számára nem elérhető, vagy olyan módon használja erőforrásait, amely nem másolható. Versenyelőny addig marad fent, amíg ezek közül az egyik fennáll. A vállalat létének oka, hogy az hatékonyabban tudja megszervezni az eröforrások felhasználását, mint ahogyan azt a piaci kapcsolatok tennék. Az elmélet választ ad arra, hogy miért eltérőek a vállalatok, és mi a stratégai menedzsment feladta. (Mit tegyen a vállalat, hogy legyenek stratégiai erőforrásai, és hogy azok újratermelödjenek, valamint ne legyenek másolhatók.) A versenyelőny olyan eröforrásokon keresztül érhető el, melyek nem érhetők el a piacon, a vállalatnak kell előállítania - eröforrások megőrzése, reprodukálása, fejlődése.

A nemzetközi értékláncok elemzése túlmutat az egyszerü make or buy döntésen, foglalkozik a hozzáadott értékkel mind a lánc egyes pontjaiban, mind azok kapcsolatában, különös tekintettel az ellátó vállalatok azon képességére, hogy fejlesszék szerepüket a láncon belül.

Penrose (1959) a vállalatot szolgáltatások létrehozására képes termékeny (jövedelmet generáló) erőforrások csoportjaként definiálja. Az erőforrásokat egy igazgatási szervezet vezeti, mely megállapítja a nyújtandó szolgáltatások jellegét és mennyiségét. 
A vállalat nem csak azért eredményes, mert jobb erőforrásokkal rendelkezik, hanem mert alkalmas az eröforrásainak hatékonyabb kihasználására.

Penrose a fenntartható versenyképesség szükségességére koncentrál, beleértve technológiai, marketing, és méretgazdaságossági kérdéseket is. Megjelenik továbbá a testre szabható tömegtermelés és a vállalat kulcskompetenciáinak fogalma is (Milberg-Winkler, 2013).

Ami a vállalati kerek mozgását illeti, a nem másolható, pótolható, vagy nehezen elérhető erőforrások megszerzésének egyik egyszerü módja az azt birtokló cég felvásárlása.

Ha felidézzük a Microsoft fejlesztési stratégiáját látjuk, hogy a saját eredményeik mellett előszeretettel integrálnak megoldásokat, szereplőket ilyen módon. A kis fejlesztő cégek számára nincs is tán szédítőbb, de mégis reális perspektíva, mint, hogy ilyen módon figyeljen fel rájuk a szakma óriása.

\section{A gazdálkodási paradigma váltás hajtóerői}

Miután felvázoltuk, hogy a vállalat, mint az igény-kielégítés szervezeti keretei hogyan, miféle üzleti kényszerböl, és miféle nem is feltétlen számszerü kalkulációk miatt váltak ilyen képlékennyé, dinamikussá, meg kell azt is vizsgálni, hogy melyet azok a tényezők, amik ezt lehetővé teszik.

Az ezredfordulóra beérettek olyan technológiai folyamatok, melyek a társadalmak életének jelentős változását fogják elhozni már a közeljövőben. A vállalat, mint a társadalom egyik fontos eleme természetesen nem fog kimaradni ezekből a változásokból, noha annak mértéke nem látható pontosan, irányai azonban igen.

A kiváltó tényezők között két alapvetőt kell kiemelnünk:

A természeti környezet problémái

Ez napjainkban ér el egy olyan kritikus tömeget, amelyik a gazdaság lényegi szereplöjévé teszi. A gondolat 1968-ban vetődött fel egy szük professzori körben, amatör mozgalmak, majd nagyvállalati krédók szintjére emelkedett. E közben és ennek hatására is a technológia fejlődése olyan irányokban mutat eredményt, ami profitábilis módon képes kezelni a környezeti ártalmak közömbösítésének ügyét. Ez egyúttal visszahat a tudatosság erősödésére, hiszen, ha van szelektív hulladékgyüjtő valahol, akkor az ember nem érezheti azt, hogy kicsi ő ezeknek a problémáknak a megoldásához.

Ezek a hatások megjelennek a marketingtöl (a recycle embléma is eladásösztönző) kezdve az állami szabályozások szigorításán keresztül, a pénzügyi befektetők minősítéséig, tehát a vállalat egész környezetét, illetve a környezetéhez viszonyát befolyásolják.

Ez a makró trend sok helyen összefonódik az informatikai forradalommal. Az on-line, illetve smart világ számos gyártási technikát kiszorított már eddig is pl. hanghordozók, de ha belegondolunk a 3D nyomtatás fejlödési lehetöségeibe, akkor szélesebb körü, radikális változásokra kell számítanunk. 


\section{Az informatika robbanásszerủ fejlődése}

Ez nagymértékben hozzájárult a tőkepiacok soha nem látott kiterjedéséhez is, és az ottani reakció sebességének növekedéséhez. Ebből fakadóan a tőkemozgások soha nem látott dinamikával történnek, beleértve a tisztán pénzügyi, de a reálgazdasági befektetéseket is. Felerősödik a vállalatfelvásárlás, az outsourcing, insourcing, fúziók, a munkaerő kölcsönzés és a távmunka. Ezek a vállalat, mint szervezetnek határait dinamizálják.

A szervezeti határok elmosódásával párhuzamosan az ágazati tevékenységi fókuszok is megváltoznak, ami jelentős változásokat fog hozni a szektoriális szerkezetben, pontosabban képlékennyé tesz annak határait is. Egy látványos példája ennek, hogy az önvezető autók gyártására létrejövő szövetségekben még egy BMW is le tud értékelődni, összeszerelő üzemmé (1. ábra).

\section{1. ábra: A termelő, fejlesztő és szolgáltató cégek összefonódása az autóiparban (részlet)}

(5) Imestment Partnership (3) Perconnel move

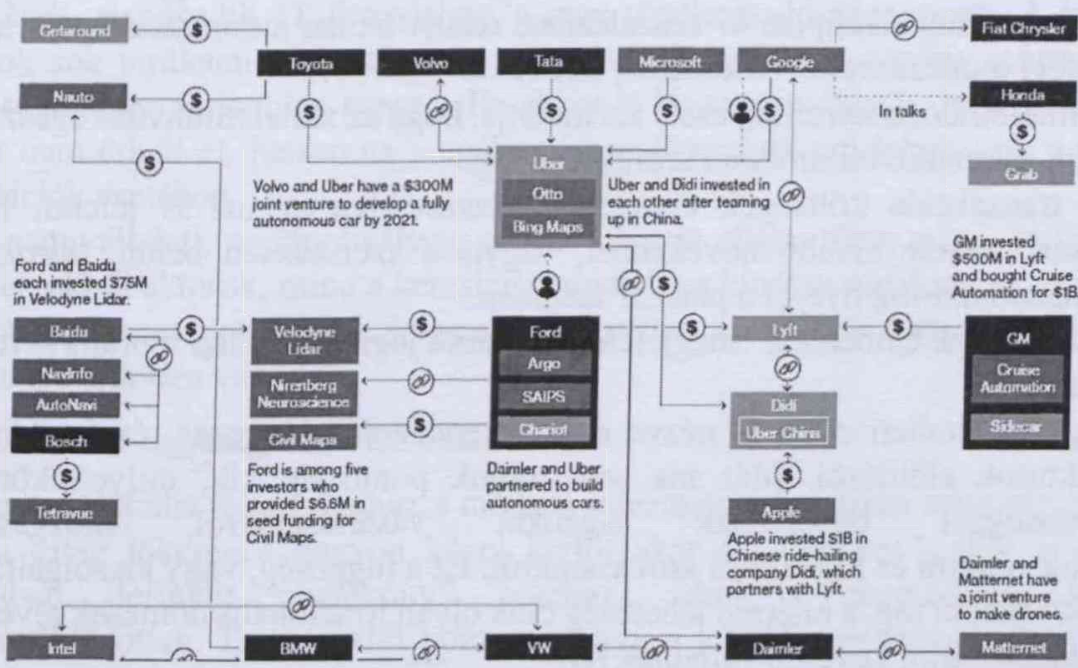

Forrás: Webb-Whiteaker, 2016

Természetesen nem csak az autóipart jellemzi ez a digitális transzformáció, de az iparág világgazdasági súlya, és társadalmi szerepe miatt is biztosak lehetünk abban, hogy ez egy áttörés az új ipar, vagy új gazdaság felé.

Részben az okos telefonok megjelenése, részben pedig az adatfeldolgozó képességet soha nem látott szintje jelenti a két további fontos változást. Az első miatt a fejlett országokban élő lakosság jelentős része lényegében folyamosan on-line kapcsolatban is áll a világgal.

Ez az iparágakon belül tapasztalható koncentrációval párhuzamosan a piacon résztvevők számának robbanásszerü növekedését jelenti. 
Ez egyrészt hihetetlen mennyiségü - kereskedelmi értelemben hasznosítható információtömeget nyújt az emberekröl, mint fogyasztókról. A cellainformációk a mozgásukról, a bankkártyás vásárlásaik a vásárlások helyéről, összegéről, a hủségpont gyüjtỏ kártyák, pedig egészen az árucikk szintű tételekről is könnyen rendszerezhető konkrét adatokat jelentenek.

Az információ feldolgozási kapacitás pedig egyre inkább lehetővé teszi ezen információk alapján egyedi profilok, és minden eddiginél részletesebb piacszegmentálás felállítását.

Annál is inkább lehetővé tesz, mert a fogyasztók maguk is szorgalmazzák ezt.

„A hüségprogramokban való részvételt a legtöbben (59\%) a vonzó ajándékkal magyarázzák, de a vásárlók harmada számára az is fontos, hogy elismerjék hüségüket." (Piac \& Profit, 2015)

Ezt természetesen marketing lényegi szerep- és tevékenységváltozását hozza el, de az IT új irányai más foglalkoztatási területeken is megváltoztatják a jelenlegi rendet.

„Az Egyesült Államokban tanulmányt készítettek a munkakörök komputerizálására és azt tapasztalták, hogy az elkövetkező egy, maximum két évtizedben a munkaerőpiac 47 százalékánál relatív hamar automatizálhatók lesznek a jelenlegi munkakörök." (Mészáros, 2014)

A hitelbíráló, kontrolling esete azt mutatja, hogy az vállalatirányítás egész rendje átalakul, és rendkívüli módon karcsúsodni fog.

A tranzakciós költségek elméletére visszautalva ez azt is jelenti, hogy a vállalatok mérete tovább növekedhet, vagyis a szervezeten belüli, bürokratikus koordináció tért fog nyerni a piaccal szemben.

$\mathrm{Az}$ „on-line emberiség” megjelenése további jogi, de inkább morális kérdéseket is elöhoz.

Egyéni, emberi oldalról nézve ezek a tendenciák lényeges, és feloldhatatlan konfliktusok elöidézői. Már ma sem tudjuk pontosan, kik, milyen körben és részletességgel birtokolnak adatokat vásárlásainkról, mozgásunkról, kapcsolatainkról és fogyasztói szokásainkról. Ez a függőség, vagy kiszolgáltatottság csak növekedni fog, a kilépési lehetőség csak olyan irracionális döntések révén volna megoldható, amit kevesen vállalnak fel.

A folyamatos elérhetőségnek ezen túl más, érdemi hatása is van a piaci müködésre.

Amíg a termelöi oldalon a koncentráció miatt csökken a szereplök száma - ezt egyensúlyozhatja az új alapítású cégek, illetve a kiszervezéssel létrejövő gyarapodás - addig a fogyasztó oldalon, legalábbis a potenciális fogyasztók köre ugrásszerüen megnö.

$\mathrm{Az}$ egyéni on-line életnek fontos területe a közösségi hálózatok aktív, és mindennapos igénybevétele is. Ez egyrészt persze reklám felületet jelent a cégek számára, de nagyobb hatása annak van, hogy a fogyasztók egymás közötti közvetlen kapcsolódása új, nem látott üzleti formák megjelenésére adott lehetőséget. Ilyenek a megosztáson alapuló igény kielégítési módok, amelyek üzleti hátterét informatikai szolgáltatások biztosítják. 
Ez tulajdonképpen az e-business $\mathrm{C} 2 \mathrm{C}$ változatának professzionalizálódása felé egy lépés, ami az üzleti vállalkozások szervezeti kereteit nem pusztán dinamizálja, hanem fel is oldja.

$\mathrm{Az}$ a szigorú elhatárolás, ami pl. a Kornai féle axióma-rendszerben alappillér, elmosódóban van, mivel a termelő és fogyasztơi szféra nem válik olyan élesen ketté, a fogyasztó-fogyasztó üzleti kapcsolatok forradalmi ütemủ növekedésével.

Sőt ami a későbbi fejlemények szempontjából még fontosabb tipikussá válik a tranzakciók három személyessé válása. A bank, mint a fizetés lebonyolításának háttere eddig is megtalálható volt a szereplök között, azonban ez mintegy technikai segítségként volt jelen, korlátozott szerepkörrel.

$\mathrm{Az}$ on-line bankolás a folyamat gyorsításán túl a tömegességével segíti a piaci szereplök számának dinamikus növekedését. A másik fontos „harmadik” fél a platformok képében lépett színre.

\section{Az új gazdaság keretei}

A piac

Úgy tünik, a második IT forradalom a piac tökéletesedéséhez vezet. A belépési korlátok sok területen eltűnnek, vagy jelenőségük csökken, a teljes informálódás lehetősége nagyságrendileg megnő. Ez akkor is lényeges változás, ha a „tökéletes” szintet nem érheti el, hiszen az magában is profittermelö erő lehet - pl. a tőzsdei spekulációk esetében.

A nagyvállalati monopolizáltság mellet - bár az aligha törve meg - milliószám kerülnek elö új aktorok, mind a keresleti, mindedig a kínálati oldalon.

Továbbra sem mondhatjuk, hogy a piac egyetlen, és örök, de mint integráló séma jócskán erősödőben van.

Az eröforrások sorrendjének változása

A tőkepiac globális fejlettségéhez a modern informatika hatalmas sebességet adott. Ezért a világ tökepiaca nagyon közel került akár a "tökéletes”, akár a szintén elméletben definiált „hatékony” piachoz., ahol a megtérülési szintek kiegyensúlyozottak. Tartós extra hozamot, vagy a jobb finanszírozás révén tartós vállalati versenyelönyt erre építve nem lehet elérni.

A globalizáció révén, a munkaerö piacon is - történelmi értelemben biztosan eröteljes kiegyenlítődés indult meg. A termelés kihelyezés, régebben, és legnagyobb értékben Kínába sokáig behozhatatlan versenyelönyt jelentett. Mára a kínai bérek is megközelítik a szerényebb Kelet-Európai bérszínvonalat, de versenyelőny még mindig megőrizhető, mert a termelés további kihelyezése Laoszba, Kambodzsába tovább táplálja ezt a folyamatot.

De mindezek ellenre, az elérhetö extraprofit csökken, és időben pedig véges lehetőségröl van szó.

Az input piacok tekintetében a tökét illetően a globális gazdaság és a fent említett tőke mobilitás a hatékony tőkepiachoz való erőteljes közeledést mutatja. A 
munkaerőt tekintve szintén egyféle - a fejlett országok dolgozói számára igen előnytelen nivelláció indult, illetve erösödött meg.

Ez egyúttal azt is jelenti, hogy befektetöi szemmel - ennek a két erőforrásnak bármiféle kombinációjával sem lehet tartós jövedelmezőségi előnyt elérni.

Ennek forrása a fenti tendenciák szerint az információ, mint erőforrás adja. Itt még hatalmas növekedési tartalékok vannak, ezeket felhasználva még lehet tartós versenyelönyre szert tenni.

A világot eluraló rendezetlen 'hír-szemétböl' hírt, majd információt és végül adatot gyártani és azt használni a fogyasztók irányába olyan ugrásszerü változást hoz a vállalati gazdálkodásba, amire nagyon régóta nem volt példa.

A tudás egyik frappáns definíciója szerint egy emberi képesség az információk felhasználására, problémák megoldása érdekében (Chikán, 2017).

A tudás fejlesztéséhez tehát az információk hatékonyabb felhasználása vezet, az a vállalkozás, amelyik ebben élenjáró, az élenjáró lesz a versenyben is, és a tulajdonosi értéknövelésben is.

Jelenleg a legértékesebbnek tekintett sharing economy vállalat az Uber és az Airbnb, nagyságukra jellemzö, hogy dinamikusan növekszik, a Wall Street Journal statisztikája szerint 2015 júliusában az Uber 157 ezer fuvart bonyolított naponta, míg az Airbnb-n keresztuil naponta 140 ezren foglaltak szállást.

Ugyanebben az időben az Uber becsült értéke meghaladta az 50 milliárd dollárt (USD), az Airbnb-t pedig 24 milliárd dollárra értékelték (Összehasonlításképpen az OTP piaci kapitalizációja ugyanebben az időben 5,7 milliárd dollár volt, a MOL-é pedig 5,4 milliárd dollár)

Ezek a cégek egyszerüen hatékony információkezeléssel foglalkoznak, tehát nem a tudástartalom fejlesztésében számítanak élenjárónak.

A tudás fontos versenyképességi tényező lett, az alapját jelentő információ (kezelés) pedig elörébb rukkol a gazdasági erőforrások között.

De ez csak átrendeződés, még, ha későbbi hatásai nem is felmérhetőek.

Az eredeti felvetésünk, tehát, hogy az a második informatikai, és negyedik ipari forradalom jelent-e az eddig megszokott piac gazdasági elveken nyugvó kapitalizmus meghaladást, nemmel kell válaszolni.

Platformok a vállalatok helyén

A platformok biztosítják a csere lehetöségének megteremtését a vállalkozók és vevők között egyfajta virtuális piactérként. Müködésük részben bizalmi alapon történik és a technológia lehetőségeinek kihasználásával csökkentik a felhasználók számára a vásárlással együtt járó tranzakciós költségeket. A vállalkozók azok a személyek vagy vállalkozások, melyek árukat és szolgáltatásokat kínálnak eladásra. A keresletet (pl. vásárlás, bérlés) mindezekre pedig a fogyasztók biztosítják. A termék vagy szolgáltatás ellenértékének kiegyenlítésére szintén általában a platform ad lehetőséget (akár külső platform bevonásával - mint a PayPal), mely ezért valamelyik félnek díjat számol fel (Osztrovits et al., 2015).

Néhány fontosabb megvalósulása a fenti lehetöségeknek: 
Eszköz alapú szolgáltatásokról beszélünk, amikor valaki meglévő, kihasználatlan vagyontárgyait adja bérbe másoknak. Az ilyen szolgáltatások terjedését segítő platformok azoknak is munkalehetőséget biztosítanak, akik nem hivatászszerüen, hanem részmunkaidőben végzik az adott foglalkozást (bérkiegészítés). Például az Airbnb szállás-megosztó piactér segítségével az emberek kiadhatják kihasználatlan ingatlanjukat, vagy azok egy részét, ez által vállalkozóvá válnak. A RelayRides és a Getaround platform lehetöséget biztosít az autótulajdonosoknak gépjármủvük rövidtávú bérbeadására.

A Fintech pedig analóg kapcsolatok megjelenését jelenti a pénzpiacokon, eröteljes fenyegetésként a bankszektor felé. A kriptovaluták pedig az egész pénzrendszer - még ha nagyon csíra állapotú - leváltásának lehetőségét is magukban hordozzák.

A platform tehát leegyszerüsíti a kereslet-kínálat találkozását, valamint lényeges segítséget nyújt a piacra lépés korlátjainak átlépéséhez.

A sharing economy sikeres müködéséhez több feltétel szükséges, melyek nélkül nem jöhet létre hasonló modell. Ezek közül a négy legfontosabb (Rinne, 2013):

- bizalom a felhasználók között

- a közös erőforrásokba vetett hit és azok kihasználásának menedzsmentje,

- kihasználatlan kapacitások

- kritikus tömeg mind a keresleti, mind a kínálati oldalon.

A neten kialakuló közösségi gazdálkodásnak érdekes, és fontos eleme a finanszírozás hálózatos megjelenése, a crowdfunding révén. Világméretben is jelentős reprezentánsai az Indiegogo és a Kickstarter.

A példákkal a jelenség rendkívül gyors terjedését szeretnénk illusztrálni.

Mindezek a változások a piaci szereplö számának ugrásszerü növelésével, a reakciók sebességnek gyorsításával lényegesen közelebb viszik a gazdaságot a „tökéletes piac” modelljéhez, másrészt viszont a piacot magát mintegy beintegrálják egy platform (és a mögötte álló vállalat) erőterébe.

Ezért az érintett vállalatok értéke villámgyorsan növekedni kezd és nem konkrét fizikai, vagy pénzügyi tőkebefektetéseik, hanem a rajtuk átfolyó információk miatt, mintha valami virtuális tőzsde cégek volnának.

Ezek a tendenciák a fogyasztói oldalon azt jelentik, hogy a fogyasztás hatékonysága nő meg. A világgazdaság eddigi fejlődését a befektetett tőkék hatékonyabb megtérülése hajtotta, úgy tünik, most új lendületet kap a fejlödés, azzal, hogy a racionális fogyasztói magatartás a korábbinál jóval kevesebb befektetéssel is képes a korábbi jólétét fenntartani.

Szintén hangsúlyos új erő a modern versenyképességben a beépített tudás mértéke, és hasznossága.

A terméken ,intangible” tartalma nő (Boda, 2016) ami régóta tartó folyamat, de minöségileg más növekedést jelent az automata autó, a fékezést segítö ABS rendszerhez képest. Ha körül nézünk a technológia által ma már üzemszerüen biztosított lehetőségek között, a Google helymeghatározás utca, és házszám szintü, a követési távolság, sávtartás, közúti jelzések értelmezése megjelent már sorozatgyártású autókban, akárcsak a parkoló algoritmus, tehát rövid időn belül 
előállhat az a helyzet, hogy a mobiltelefonos applikáción nem Uber szolgáltatót, hanem egy üres, intelligens autót fogunk rendelni.

A gépek on-line életének fontos terepe lehet a szervizelés, de még a gyártástechnológiák lényegi megváltozása is. A termelési folyamatirányítás, mint emberi tevékenység is háttérbe fog szorulni a lényegében valós idejü optimalizáló algoritmusok mellett. Ennek apró, de fontos jele, hogy a ma, Magyarországon hiányzó 10 ezer körüli informatikus nem a vállalati rendszergazda, vagy webfejlesztő munkakörből, hanem a legdirektebb ipari területröl hiányzik.

Ezek a tendenciák sok esetben inkább közeledést jelentenek a „tökéletes” piac alapelvei felé, noha a piac maga, mint koordinációs mechanizmus jókora területeken, a vállalaton belülre helyezödik.

A platform tehát olyan entitásként írható le, ami a vállalat klasszikus kereteibe helyezi a piaci integráló sémát. Ezzel nem a piac egyik lényegi szereplöje (a fogyasztó mellett), hanem a fogyasztó számáéra mutatott kínálaté, és annak elérési mechanizmusa is egyben.

A bevezetőben említett hármas feltételrendszer: piac, vállalat, tőke vezérelt gazdaságból, úgy tủnik a vállalat szerepe az, ami forradalmi változásnak indult.

Határai képlékenyek és dinamikusak, hatóköre nem pusztán a vevö kiszolgálására korlátozódik, hanem a fogyasztót is kínálatra bírva lényegesen kiterjeszti a gazdasági tranzákciók volumenét, tőkebevonás nélkül, az informatika második forradalmára építve.

\section{Irodalomjegyzék}

Boda Gy. (2016): Ez volna tudásalapú gazdaság? BCE Vállalatgazdaságtani Intézet, vitairat.

Chikán A. (2017): Válallatgazdaságtan. Vállalatgazdasági Tudományos és Oktatási Alapítvány, Budapest.

Coase, R. (1937): The Nature of the Firm. Economica, New Series, 4 (16): 386-405.

Gereffi, G., Humphrey, J., Sturgeon, T. (2005): The governance of global value chains. Review of International Political Economy, 12 (1): 78-104. <https://www.fao.org/fileadmin/user_upload I.../docs/GVC_Governance.pdf> (2016.06.21.)

Grossman, G. M., Helpman, E.: Outsourcing in a Global Economy. Review of Economic Studies. 72 (1): $135-159$.

Kornai J. (1971): Antiequiblirum. Közgazdasági és Jogi Kiadó, Budapest.

Langlois, R. N. (2003): Strategy as economics versus economics as strategy. John Wiley \& Sons, Ltd. Mészáros E. (2014): Modell, soför, hitelelemzö - hamarosan robotok veszik át a munkájukat. HR Portal. <http://www.hrportal.hu/hr/modell-sofor-hitelelemzo-hamarosan -robotok-veszik-at-amunkajukat-20140916.html> (2016.04.21)

Milberg, W., Winkler, D. (2013): Outsourcing Economics. Cambridge University Press, Cambridge. North, D. C. (1990): Institutions, Institutional Change and Economic Performance. Cambridge University Press, Cambridge.

Osztrovits Á., Köszegi Á., Nagy B., Damjanovics B. (PricewaterhouseCoopers) (2015): Osztogatnak vagy fosztogatnak? A sharing economy térnyerése. <http://www.pwc.com/hu/hu/ kiadvanyok/sharing_economy_ternyerese.html> (2016.04.20.)

Penrose, E. (1959): The Theory of the Growth of the Firm. Oxford University Press Inc., New York.

Piac \& Profit: Tarolnak a hüségprogramok. In: Piac \& Profit [elektronikus folyóirat] <http://www.piacesprofit.hu/kkv_cegblog/tarolnak-a-husegprogramok/> (2015.10.11.) 
Rinne, A. (2013): Innovation \& New Business ModelsDialogue, Young Global Leaders Sharing Economy Dialogue Position Paper :World Economic Forum, Young Global Leaders Circular Economy.

Sztanó I., Veress A. (2013): A vezetői számvitel. <http://www.tankonyvtar.hu/ hu/tartalom/tamop412A/0007_a2_1038_1039_1041_bavezetoiszamvitel/4_2_3_2_2_a_teveke nysegalapu_kalkulacio_TilVgJSblbLg79UI.html>

(2017.06.12.)

Webb, A., Whiteaker, Ch. (2016): Technology and Car Companies Are More Intertwined Than Ever <https://www.bloomberg.com/graphics/2016-merging-tech-and-cars/> (2018.06.14.)

Wernerfelt, B. (1984): A Resource-Based View of the Firm. Strategic Management Journal, 5 (2): 171-180. <http://links.jstor.org/sici?sici=0143-2095\%28198404\%2F06\%295\%3A2\%3C171\% 3AARVOTF\%3E2.0.CO\%3B2-L (2017.06.20)

Williamson, O. E. (1996): The Mechanisms of Governace. Oxford University Press. 